\title{
Innovation and Entrepreneurship Training to Empower Catfish Farmers
}

\author{
Luqman Khakim ${ }^{1, *}$, Sartono Sartono ${ }^{2}$, Iwan Hermawan ${ }^{1}$, Agung Sudaryono ${ }^{3}$, Iwan Z. Fuad ${ }^{4}$ \\ ${ }^{1}$ Business Administration Department of Politeknik Negeri Semarang, Semarang - Indonesia \\ ${ }^{2}$ Syariah Banking Department of Politeknik Negeri Semarang, Semarang - Indonesia \\ ${ }^{3}$ Fisheries and Marine Science Faculty of Universitas Diponegoro, Semarang - Indonesia \\ ${ }^{4}$ Syariah Faculty of IAIN Pekalongan - Indonesia
}

\begin{abstract}
Many residents of Siwatu Village of Batang Regency employ their land to produce catfish. This fish is chosen because it can be harvested in a relatively short time with simple maintenance. However, being a catfish farmer is not as easy as imagined. Many obstacles have to be overcome, such as, lack of availability of seeds, the high cost of catfish feed, the lack of capital and the dominant role of loan sharks in the catfish trade in Siwatu. The paper objectives are to describe strategic steps in assisting catfish famers to survive in the industrial competition through innovation and entrepreneurship training. Solutions offered in the form of institutional strengthening, feed production innovation, increased valueadded product, entrepreneurship training for the fish farmers and connecting to advisory agency.
\end{abstract}

Keywords: Innovation, Entrepreneurship, Entrepreneurs

\section{Introduction}

Residents in Siwatu Village, Batang Regency, are mostly factory workers. To earn extra income, they use their land to produce catfish. This fish is selected because it can be harvested in a relatively short time with simple maintenance. In the village, there is a group of catfish farmers namely Karya Mulia. Unfortunately, the group had been inactive for some years, thus, the effectiveness of the group deteriorated.

Being a catfish farmer is not simple. It needs adequate capital and skills. Many catfish entrepreneurs in Siwatu Village without sufficient preparation have trapped on loan sharks. It is because they lack of capital to produce catfish after their harvest were failed. Furthermore, the loan sharks had provided loans to them, in the form of seeds and catfish feed called pellets during catfish farming time. The rewards they were required to sell the proceeds to the loan sharks at a price determined by the loan sharks. As a result, they were dictated by the loan sharks, subsequently, their welfare had decreased.

The paper objective is to describe strategic steps in serving catfish farmers to survive in the industrial competition through innovation and

\footnotetext{
${ }^{*}$ Corresponding author e-mail luqman.khakim@polines.ac.id
}

entrepreneurship training. Solutions offered in the form of institutional strengthening, feed production innovation, increased value-added products, entrepreneurship training for the fish farmers and connecting to advisory agency.

\section{Methodology}

Observation is conducted to identify and prioritize problems to be solved. Based on the problems priority, the method of solving the problems formulated considering the needs, the resources owned and the commitment of the farmers.

\section{Discussion}

Catfish industry in Siwatu Village of Batang Regency in particular and possibly throughout Indonesia requires a business model that refers to innovative business practices. At the same time, it needs to provide entrepreneurship training to catfish farmers, to 
encourage them able to handle managerial problems they encountered and survive in a competitive business environment.

To solve the problems undergone by catfish farmers, the first step taken is strengthening institution by providing computers to the Karya Mulia group and holding an organizational workshop. It is important to ensure the group has capacity to manage various activities of its members and able to provide more value for its members [1][2]. Thus, the farmers are aware of the advantages of being member of the group and willing to join the group [3]. Working together in a group will escalate the scale of the business. Therefore, their works will more efficient and have bargaining power to their suppliers and consumers. The group may create planting and harvesting schedule that employed to stabilize their catfish supply for catfish whole sellers.

The problem of the needs of catfish seeds for the farmers has been overcome with two steps. The first was collected seed demand data and seed production capacity data. Second, seeds farmers and enlargement farmers brought together of catfish fellow members of the Karya Mulia. Sales-purchase agreements on credit have conducted between both parties ( 3 months) which are managed by the group. Funding is handled by the group. If there is still funding shortage it would be financed from borrowing funds of PNPM (financial institution of Siwatu Village of Batang District). Thus, catfish farmers are free from the loan sharks and able to sell their business to the group or market at a reasonable price.

Catfish feed provider unit held to overcome the lack of catfish feed called pellet. The unit received support from "Science and technology project for the community" from Ministriy of Research and Technology and Higher Education of Indonesia, in the form of pellet machine with a capacity of about 20 $\mathrm{kg} /$ hour. The head trained to produce floating pellet with food conversion ratio of 1 . The price of pellet made by factory is Rp. $9.500 / \mathrm{kg}$, while if made by the unit, the cost is only Rp. $5.500 / \mathrm{kg}$. Thus, the farmers receive significant cost reductions, about $42 \%$.

Increasing the added value of catfish products is also very important to improve the welfare of farmers. Usually, the farmers sell live catfish, content of 10 catfish $/ \mathrm{kg}$ for about Rp. $16.000 / \mathrm{kg}$. In order to increase the added value, the catfish needs to be processed into a higher value product. One of the competitively product is fish shredded, namely Abon. The abon is a traditional food without preservatives that are easily made by the community. The quality of the abon from catfish is similar with the abon from cow meat. To produce $1 \mathrm{~kg}$ of catfish abon required 5 $\mathrm{kg}$ of catfish meat. The total costs of manufacturing abon are Rp. 228.850, while, the selling price is Rp.
$276.000 / \mathrm{kg}$. Thus, the farmers obtained profit of $17.4 \%$. Furthermore, the packaging labels are designed to increase the value of the catfish abon product. It is important, considering the packaging design as the first step in branding product. In addition, selected packaging is eligible to package the food and provide better promotional value.

An entrepreneurship workshop held. It is employed to train the farmers to recognize business opportunities, plan the business, implement the plan included the sanitation and fishing procedure to create clean environment and hygiene food production, and evaluate it. The entrepreneurship training has a positive impact on the implementation of management in their business [4]. Thus, the welfare of farmers increases. In addition, those works are finalized with connecting the farmers to fisheries agency of Batang Regency to gain regular advisories.

\section{Conclusion}

Breeding catfish is a side job for Siwatu residents of Batang Regency, considering the ease in operation and the duration required is relatively short. However, the limited capital entrapped many farmers on loan sharks. To overcome it, institutional strengthening, feed production innovation, value-added product enhancement and entrepreneurship training for farmers are set up. The farmers also hooked up to fisheries agency of Batang Regency to earn regular assistances.

\section{References and Notes}

1. Y. H. Sandyatma and S. S. Hariadi, Kawistara, 2 225-328 (2012).

2. G. Bonazzi and M. Iotti, American Journal of Applied Sciences 11 1181-1192 (2014).

3. D. K. Swastika and Y. Supriyatna, "The Characteristics of Poverty and Its Alleviation in Indonesia", Retrieved from www.ejurnal.litbang.pertanian.go.id on 15 September 2017 (2016).

4. A. B. C. Ezeibe, E. C. Okorji, J. M. Chah and R. N. Abudei, African Journal of Agricultural Research, 9 1604-1609 (2014). 